\title{
News vs. Entertainment: How Increasing Media Choice Widens Gaps in Political Knowledge and Turnout
}

\author{
Markus Prior Princeton University
}

\begin{abstract}
Despite dramatic increases in available political information through cable television and the Internet, political knowledge and turnout have not changed noticeably. To explain this seeming paradox, I argue that greater media choice makes it easier for people to find their preferred content. People who like news take advantage of abundant political information to become more knowledgeable and more likely to turn out. In contrast, people who prefer entertainment abandon the news and become less likely to learn about politics and go to the polls. To test this proposition, I develop a measure of people's media content preference and include it in a representative opinion survey of 2,358 U.S. residents. Results show that content preference indeed becomes a better predictor of political knowledge and turnout as media choice increases. Cable TV and the Internet increase gaps in knowledge and turnout between people who prefer news and people who prefer entertainment.
\end{abstract}

T he rise of new media has brought the question of audience fragmentation and selective exposure to the forefront of scholarly and popular debate. In one of the most widely discussed contributions to this debate, Sunstein (2001) has proposed that people's increasing ability to customize their political information will have a polarizing impact on democracy as media users become less likely to encounter information that challenges their partisan viewpoints. While this debate is far from settled, the issue which precedes it is equally important and often sidestepped: as choice between different media content increases, who continues to access any type of political information? Cable television and the Internet have increased media choice so much in recent decades that many Americans now live in a high-choice media environment. As media choice increases, the likelihood of "chance encounters" (Sunstein) with any political content declines significantly for many people, as this study will demonstrate. Greater choice allows politically interested people to access more information and increase their political knowledge. Yet those who prefer nonpolitical content can more easily escape the news and therefore pick up less political information than they used to. In a highchoice environment, lack of motivation, not lack of skills or resources, poses the main obstacle to a widely informed electorate.

As media choice increases, content preferences thus become the key to understanding political learning and participation. In a high-choice environment, politics constantly competes with entertainment. Until recently, the impact of content preferences was limited because media users did not enjoy much choice between different content. Television quickly became the most popular mass medium in history, but for decades the networks' scheduling ruled out situations in which viewers had to choose between entertainment and news. Largely unexposed to entertainment competition, news had its place in the early evening and again before the late-night shows. Today, as both entertainment and news are available around the clock on numerous cable channels and web sites, people's content preferences determine more of what those with cable or Internet access watch, read, and hear.

Distinguishing between people who like news and take advantage of additional information and people who

Markus Prior is assistant professor of politics and public affairs, Woodrow Wilson School of Public and International Affairs, Princeton University, 313 Robertson Hall, Princeton, NJ 08544-1013 (mprior@princeton.edu).

I am grateful to David Brady, the Center for the Study of Democratic Politics at Princeton, and Knowledge Networks for providing support for this project. Larry Bartels, Matt Baum, Michael Delli-Carpini, John Geer, Marty Gilens, Jay Hamilton, Shanto Iyengar, Skip Lupia, Tali Mendelberg, Diana Mutz, Sam Popkin, Wendy Rahn, and the anonymous referees deserve thanks for many helpful comments on previous versions of this article.

American Journal of Political Science, Vol. 49, No. 3, July 2005, Pp. 577-592 
prefer other media content explains a puzzling empirical finding: despite the spectacular rise in available political information, mean levels of political knowledge in the population have essentially remained constant (Delli Carpini and Keeter 1996; Gilens, Vavreck, and Cohen 2004). Yet the fact that average knowledge levels did not change hides important trends: political knowledge has risen in some segments of the electorate, but declined in others. Greater media choice thus widens the "knowledge gap" (Tichenor, Donohue, and Olien 1970). Following Tichenor and colleagues's formulation of the knowledge gap hypothesis, numerous studies have examined the diffusion of information in the population and the differences that emerge between more and less informed individuals (for reviews see Gaziano 1997; Viswanath and Finnegan 1996). According to some of these studies, television works as a "knowledge leveler" (Neuman 1976, 122) because it presents information in less cognitively demanding ways (Eveland and Scheufele 2000; Kwak 1999). To reconcile this effect with the hypothesis that more television widens the knowledge gap, it is necessary to distinguish the effect of news exposure from the effect of the medium itself. In the low-choice broadcast environment, access to the medium and exposure to news were practically one and the same, as less politically interested television viewers had no choice but to watch the news from time to time (more on this below). As media choice increases, exposure to the news may continue to work as a "knowledge leveler," but the distribution of news exposure itself has become more unequal. Access to the medium no longer implies exposure to the news. Television news narrows the knowledge gap among its viewers. For the population as a whole, more channels widen the gap.

The consequences of increasing media choice reach beyond a less equal distribution of political knowledge. Since political knowledge is an important predictor of turnout and since exposure to political information motivates turnout, the shift from a low-choice to a high-choice media environment implies changes in electoral participation as well. Those with a preference for news not only become more knowledgeable, but also vote at higher rates. Those with a stronger interest in other media content vote less.

This study casts doubt on the view that the socioeconomic dimension of the digital divide is the greatest obstacle to an informed and participating electorate. Many casual observers emphasize the great promise new technologies hold for democracy. They deplore current socioeconomic inequalities in access to new media, but predict increasing political knowledge and participation among currently disadvantaged people once these in- equalities have been overcome (e.g., National Telecommunications and Information Administration 2002; Negroponte 1995). This ignores that greater media choice leads to greater voluntary segmentation of the electorate. The present study suggests that gaps based on socioeconomic status will be eclipsed by preference-based gaps once access to new media becomes cheaper and more widely available. Gaps created by unequal distribution of resources and skills often emerged due to circumstances outside of people's control. The preference-based gaps documented in this article are self-imposed as many people abandon the news for entertainment simply because they like it better. Inequality in political knowledge and turnout increases as a result of voluntary, not circumstantial, consumption decisions.

After presenting the theoretical framework that predicts changes in knowledge and turnout, two studies test this theory empirically. The first study is based on a nationally representative survey I designed specifically to measure content preferences and relate them to political knowledge and turnout. The second study relies on data collected by the National Election Studies and the Pew Research Center for the People and the Press. Although the preference measures are considerably weaker in the second study, they allow replication of the results for a longer time period and different modes of (survey) data collection.

\section{Theory}

The basic premise of this analysis is that people's media environment determines the extent to which their media use is governed by content preferences. According to theories of program choice, viewers have preferences over program characteristics (Bowman 1975; Lehmann 1971) or program types (Youn 1994) and select the program that promises to best satisfy these preferences. The simplest models distinguish between preferences for information and entertainment (Baum 2002; Becker and Schönbach 1989; Rubin 1984). In the low-choice broadcast environment, most people watched news and learned about politics because they were reluctant to turn off the set even if the programs offered at the time did not match their preferences. One study conducted in the early 1970 s showed that $40 \%$ of the respondents reported watching programs because they appeared on the channel they were already watching or because someone else wanted to see them (LoSciuto 1972). Audience research has proposed a two-stage model according to which people first decide to watch television and then pick the available program they like best. Klein aptly called this model the "Theory of Least 
Objectionable Program" (1972, 77). If television viewers are routinely "glued to the box" (Barwise, Ehrenberg, and Goodhardt 1982) and select the best available program, we can explain why so many Americans watched television news in the 1960s and 70s despite modest political interest. Most television viewing in the broadcast era did not stem from a deliberate choice of a program, but rather was determined by convenience, availability of spare time and the decision to spend that time in front of the TV set. And since broadcast channels offered a solid block of news at the dinner hour and again after primetime, many viewers were routinely exposed to news even though they watched television primarily to be entertained:

Those viewers who can be counted on to watch a news program are not at all drawn to their set from their various pursuits by the appeal of the program; for the main part they are already watching television at that hour, or disposed to watch it then, according to the audience-research studies that networks have conducted over the years. (Epstein 1973, 90)

Once exposed to television news, people learn about politics (e.g., Neuman, Just, and Crigler 1992; Zhao and Chaffee 1995). Although a captive news audience does not exhibit the same political interest as a self-selected one and therefore may not learn as much, research on passive learning (Krugman and Hartley 1970) suggests that even unmotivated exposure can produce learning (Keeter and Wilson 1986; Zukin and Snyder 1984). According to Graber, "[p] eople who are exposed to large amounts of news will remember many stories despite lack of interest because mere exposure produces learning" (1988, 114). Hence, even broadcast viewers who prefer entertainment programs absorb at least basic political knowledge when they happen to tune in when only news is on.

I propose that such accidental exposure should become less likely in a high-choice environment because greater horizontal diversity (the number of genres available at any particular point in time) increases the chance that viewers will find content that matches their preferences. The impact of one's preferences increases, and "indiscriminate viewing" becomes less likely (Youn 1994). Cable subscribers' channel repertoire (the number of frequently viewed channels) is not dramatically higher than that of nonsubscribers (Heeter 1985), but their repertoire reflects a set of channels that are more closely related to their genre preferences. Two-stage viewing behavior thus predicts that news audiences should decrease as more alternatives are offered on other channels. Indeed, local news audiences tend to be smaller when competing entertainment programming is scheduled (Webster 1984; Webster and Newton 1988). Baum and Kernell (1999) show that cable subscribers, especially the less informed among them, are less likely to watch the presidential debates than otherwise similar individuals who receive only broadcast television. According to my first hypothesis, the advent of cable TV increased the knowledge gap between people with a preference for news and people with a preference for other media content.

Internet access should contribute to an increasing knowledge gap as well. Although the two media are undoubtedly different in many respects, access to the Internet, like cable, makes media choice more efficient. Yet, while they both increase media users' content choice, cable TV and the Internet are not perfect substitutes for each other. Compared at least to dial-up Internet service, cable offers greater immediacy and more visuals. The web offers more detailed information and can be customized to a greater extent. Both media, in other words, have unique features, and access to both of them offers users the greatest flexibility. For instance, people with access to both media can watch a campaign speech on cable and then compare online how different newspapers cover the event. Depending on their needs or the issue that interests them, they can actively search a wealth of political information online or passively consume cable politics. Hence, the effects of cable TV and Internet access should be additive and the knowledge gap largest among people with access to both new media.

There are several reasons why exposure to political information increases the likelihood that an individual will cast a vote on election day. Exposure increases political knowledge, which in turn increases turnout (e.g., Delli Carpini and Keeter 1996; Verba, Schlozman, and Brady 1995) because people know where, how, and for whom to vote. Furthermore, knowledgeable people are more likely to perceive differences between candidates and thus less likely to abstain due to indifference (Palfrey and Poole 1987). Independent of learning effects, exposure to political information on cable news and political web sites is likely to increase people's campaign interest (e.g., Bartels and Rahn 2000). Interest, in turn, affects turnout even when one controls for political knowledge (Verba, Schlozman, and Brady 1995). Entertainment fans with a cable box or Internet connection, on the other hand, will miss both the interest- and the information-based effect of broadcast news on turnout. My second hypothesis thus predicts a widening turnout gap in the current environment, as people who prefer news vote at higher rates and those with other preferences increasingly stay home from the polls. 


\section{Study 1: The News and Entertainment Survey}

\section{Data and Measures}

Demonstrating the assumed dynamic nature of widening gaps in knowledge and turnout with survey data requires a panel design, because only a panel design can show that knowledge levels changed over time. According to my theory, people with both a preference for news and access to cable and/or the Internet become more knowledgeable over time, while the opposite holds true for people who prefer entertainment programming and can choose between many different channels. According to a possible alternative hypothesis, more knowledgeable respondents who prefer news are more likely to have access to cable or the Internet in the first place than those who know less but are equally interested. If the reverse happens for respondents who prefer entertainment, an interaction effect of content preferences and media access emerges, but the knowledge gap would not in fact have widened as a result of greater media choice.

To evaluate these competing hypotheses, I designed the News \& Entertainment (N\&E) Survey, a panel survey of 2,358 randomly selected U.S. residents. It was conducted by Knowledge Networks in two waves in 2002 and 2003. Knowledge Networks interviews national probability samples over the Internet by providing a large panel, selected through Random Digit Dialing, with WebTV units and free Internet connections in exchange for taking surveys. The participants for this study constitute a randomly selected subset of the KN panel and are thus close to a random sample of the U.S. adult population. ${ }^{1}$ The first survey wave was conducted in February and March 2002, the second wave in April 2003. Of the 2,358 first-wave respondents, the 1,957 who were still part of the Knowledge Networks panel in April $2003^{2}$ were contacted again. Of these, 1,650 panelists were reinterviewed, generating a reinterview rate of $84 \%$.

Each panel wave includes a large set of political knowledge questions about current political events, political officeholders, as well as institutions and processes. It is

${ }^{1}$ The household cooperation rate during the period of the two surveys was $53 \%$. The survey completion rate for the first wave was $85 \%$. For details on the sampling mechanism used by Knowledge Networks, see Krotki and Dennis (2001). In a comparison of KN data to an RDD telephone survey, Krosnick and Chang (2001) found the KN sample to be representative of the U.S. population in terms of demographics and political attitudes.

\footnotetext{
${ }^{2}$ Almost all of the remaining 400 respondents had voluntarily withdrawn from the KN panel by the time of the second survey wave. Since few of the surveys KN panelists complete cover politics, this panel attrition should not be of great concern for my analysis. Empirically, respondents who withdrew did not differ significantly on key variables from respondents who remained active (see below).
}

unclear if panel analyses of political learning should include the same items in both surveys. If different items are used, the two knowledge scales might tap different dimensions of knowledge. If the items are identical, the first interview might encourage panelists to find (or better remember) the answers. I exactly repeated a few items and used similar types of questions in the remaining cases. The appendix lists all knowledge questions and provides summary statistics for the resulting knowledge scales. Data on turnout come from the second panel wave of the N\&E Survey. Respondents were asked whether or not they voted in the 2002 House elections. Cable access is coded as a dummy variable based on the question "Do you have either cable or satellite television?” Eighty-one percent of the respondents have cable access. Respondents are defined to have Internet access if they connect to the Internet using their home computers. ${ }^{3}$ Thirty-eight percent fall in this category; $33 \%$ have access to both new media.

At any given time, television viewers must commit to one particular program. They can either watch entertainment or news, but not both. This notion implies that viewers evaluate the different programming options relative to each other. To assess respondents' preferences for news relative to other programming genres, they were shown a list of 10 genres and asked to select the one they liked best:

Science Fiction shows like X-Files or Star Trek Voyager

Comedy/Sitcoms like Friends or The Simpsons

Drama shows like ER or Law and Order

Soap Operas like General Hospital or One Life to

Live

Reality TV shows like Survivor or Cops

Sports

Game Shows like Jeopardy or Who Wants to be a Millionaire?

News

Documentary programs on channels like History

Channel or Discovery Channel

Music Videos

After respondents marked their favorite genre, the next screen showed them the remaining nine genres and again asked for the most-liked. This procedure was repeated twice more, yielding a ranking of respondents' four most-preferred television genres. Then, respondents were given a chance to mark all of the remaining genres that

\footnotetext{
${ }^{3}$ As Knowledge Networks conducts interviews through WebTV, all respondents in the N\&E Survey have basic Internet access on their television. Study 2 uses samples that include respondents without any web access. I discuss the implications of this difference below.
} 
TABle 1 The Effect of Content Preferences on Political Knowledge (Study 1)

\begin{tabular}{lccc}
\hline & $(1)$ & $(2)$ & $(3)$ \\
\hline Cable Access & $.43(.44)$ & $.13(.21)$ & $.40^{*}(.19)$ \\
Internet Access & $.66^{*}(.39)$ & $.42^{*}(.19)$ & $.04(.16)$ \\
Relative Entertainment Preference (REP) & $.03(.12)$ & $-.05(.06)$ & $-.02(.05)$ \\
REP $\times$ Cable & $-.23^{*}(.14)$ & $-.03(.07)$ & $-.10^{*}(.06)$ \\
REP $\times$ Internet & $-.22^{*}(.11)$ & $-.15^{* *}(.05)$ & $-.03(.05)$ \\
Wave 1 Political Knowledge & $.93^{* *}(.03)$ & - & - \\
Civics Knowledge & - & $.72^{* *}(.04)$ & $.62^{* *}(.03)$ \\
Political Efficacy & $.63^{*}(.31)$ & $.57^{* *}(.15)$ & $.39^{* *}(.13)$ \\
Education & $.15^{*}(.06)$ & $.10^{* *}(.03)$ & $.17^{* *}(.03)$ \\
Income & $.05^{* *}(.02)$ & $.02^{*}(.01)$ & $.02^{* *}(.01)$ \\
R's primary language is English & $2.39^{* *}(.43)$ & $.22(.25)$ & $-.06(.18)$ \\
Gender & $-.34^{* *}(.14)$ & $-.27^{* *}(.07)$ & $-.33^{* *}(.06)$ \\
Age & $.03^{* *}(.005)$ & $.002(.002)$ & $.003(.002)$ \\
TV Households, Nielsen 2002-03 (in 1,000,000) & $.04(.04)$ & $.03(.02)$ & $.01(.02)$ \\
R owns home computer & $.15(.19)$ & $.01(.10)$ & $.13(.08)$ \\
Constant & $-3.98^{* *}(.71)$ & $1.83^{* *}(.37)$ & $2.01^{* *}(.30)$ \\
$\mathrm{R}^{2}$ & .48 & .33 & .30 \\
$\mathrm{~N}$ & 1,571 & 1,577 & 2,250 \\
\hline
\end{tabular}

${ }^{* *} \mathrm{p}<.01,{ }^{*} \mathrm{p}<.05$ (one-tailed).

Note: Cell entries are OLS coefficients and standard errors in parentheses.

they "really dislike." For the purpose of this study, I am only interested in the ranking of news vis-à-vis all other genres. The appeal of news is greatest for respondents who select news as their favorite genre. At the opposite end are respondents who specifically mark news as one they dislike. ${ }^{4}$ The measure of people's relative preferences for entertainment over news (to which I will refer as Relative Entertainment Preference or REP) is thus coded 5 if the respondent dislikes news, 4 if the respondent neither dislikes it nor selects it as one of her top four genres, and $3,2,1$, and 0 if the respondent selects news as her fourth-, third-, second- or most-liked genre, respectively. ${ }^{5}$ Exactly half of the respondents are indifferent to news, neither ranking it nor marking it as "disliked." Three percent dislike news explicitly and the remaining respondents rank it fourth $(17 \%)$, third (14\%), second (11\%), or first (5\%). The preference distribution among second-wave respondents differs minimally (by no more than 1 percentage

\footnotetext{
${ }^{4}$ This measure assumes that people either have preferences over genres or can generalize from particular program examples for each genre. I designed a second measure of content preferences that asked about liking of news and entertainment in general without mentioning genres or programs. The different measures of the same concept are strongly correlated and yield essentially the same results.

${ }^{5}$ I use a linear specification for simplicity. My theory does not necessarily imply linear effects, and quadratic or logarithmic transformations of REP indeed produce similar results.
}

point per category) from the whole sample, indicating that respondents with a preference for entertainment were no more or less likely to complete the second survey. Similarly, the difference in political knowledge between first- and second-wave respondents is insignificant. With respect to the key variables, in other words, panel attrition is not a threat.

\section{Analysis}

When television viewers have a choice between different media content, their preferences should predict what programs they will select and, by extension, how much they will learn about politics. Relative Entertainment Preference (REP) should thus impact political knowledge significantly more among cable subscribers than among nonsubscribers. Similarly, REP should have a stronger effect for Internet users. To test these hypotheses, political knowledge is regressed on cable and Internet access, REP, and the interaction between REP and media access. ${ }^{6}$ The dependent variable in the first model shown in Table 1

\footnotetext{
${ }^{6}$ I include control variables to account for alternative explanations of political learning. As cable is not affordable for all Americans, access is correlated with demographic variables, notably income and education. Also included are measures of the respondent's media environment that do not directly affect media choice (e.g., the size of the respondent's media market).
} 


\section{FIgURE 1 Political Knowledge and Relative Entertainment Preference}

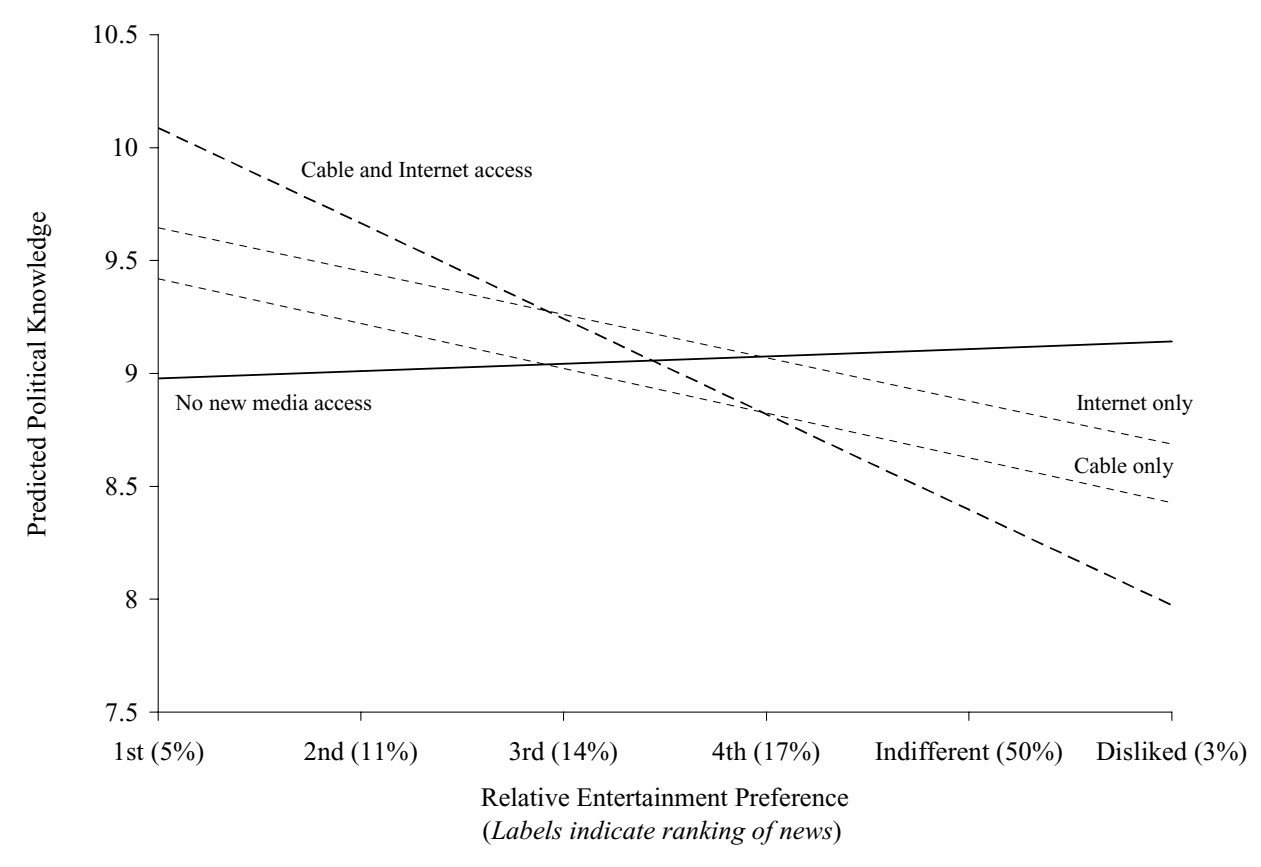

Note: The graph plots the predicted values based on model 1 in Table 1.

is political knowledge as measured in the second wave of the N\&E panel. All independent variables are from the first wave and were measured a year before the dependent variable. The joint effect of preference and media access as of spring 2002 on political knowledge a year later is tested, while controlling for knowledge differences in 2002. Controlling for the lagged value of the dependent variable reduces problems of selection bias or reverse causation, because the change in knowledge between the two waves cannot affect first wave content preferences.

Model 1 provides clear support for the predicted effect of increased media choice. The two interactions of cable and Internet access with Relative Entertainment Preference are statistically significant in the predicted direction. The two main effects of media are sizable and positive, indicating that greater choice significantly increased political knowledge between the two panel waves

I excluded 23 respondents who revealed a lack of effort from all analyses of the N\&E Survey. These respondents were identified by checking response set on two other measures of content preferences. Respondents answered five or six questions arranged on two screens in grid form. The 23 respondents were excluded because they selected the same response for all items on a screen (even though the orientation of questions varied). I also excluded six respondents who answered all or all but one current events question correctly in Wave 1, but only one or none at all in Wave 2. These dramatic differences probably arise because respondents lacked the motivation to complete the knowledge items in the second wave. for respondents with a weak entertainment preference. (Individually, only one of them reaches conventional levels of statistical significance, but their joint effect is different from zero at $\mathrm{p}=.05$.) To illustrate the interactions, Figure 1 plots the predicted values for different levels of media choice. REP has little effect on political knowledge for respondents with neither cable nor Internet access. In a media environment where you cannot choose between entertainment and news, it does not matter very much if you prefer one or the other. Among those with access to both new media, on the other hand, the difference between highest and lowest REP amounts to a knowledge gain of about $27 \%$. Compared to the modal category-indifference toward the news-new media users who rank news first or second are still 16\% more knowledgeable.

The strong impact of content preferences is perhaps most clearly demonstrated by a comparison with the effect of education, typically one of the strongest predictors of political knowledge (Delli Carpini and Keeter 1996). Both variables have the same range ( $0-5$ for REP, $1-6$ for education) and similar distributions (their standard deviations are nearly identical at 1.26 for education and 1.27 for REP). The size of each interaction effect exceeds the impact of education. The change in knowledge associated with the difference between the most and the least educated respondents is about $9 \%$, compared to the $27 \%$ change for the full range of REP among new media users. 
In a high-choice environment, people's content preferences become better predictors of political learning than even their level of education.

By assessing the change in political knowledge compared to a baseline set by performance in the first panel wave, the panel design provides a very rigorous test of my hypotheses. A cross-sectional design still makes it possible to show static gaps in knowledge (rather than learning over time) among people with greater media access. In the cross-sectional case, however, the "baseline" cannot be knowledge assessed at an earlier point in time. Instead, I use knowledge that respondents presumably acquired earlier. Knowledge about governmental processes and institutions probably fits that description both because it is emphasized in civics education and because the correct answers do not change as frequently as for questions about current events. The dependent variable in columns 2 and 3 of Table 1 is thus Wave 1 knowledge of current affairs, while civics knowledge, also measured in Wave 1, serves as a control variable. ${ }^{7}$ Column 2 includes only respondents who were also interviewed in Wave 2, while column 3 shows the same model for all Wave 1 respondents.

The results for the cross-sectional analysis are weaker than for the panel setup. Individually, only one of the two interaction effects is significant in each model. In both models, however, the addition of cable access, Internet access, and their interactions with REP increases the model fit significantly $[\mathrm{F}(1,1562)=3.5, \mathrm{p}=.06$ for column $2, \mathrm{~F}(1,2235)=3.1, \mathrm{p}=.08$ for column 3 ]. Bearing in mind later analyses in this article, it is useful to know that even cross-sectional data analysis can demonstrate the presence of wider knowledge gaps between news and entertainment fans in a high-choice media environment. Below, I take advantage of the greater availability of cross-sectional data to replicate the results obtained in this section.

\section{Turnout}

Increasing penetration of new media technologies should increase the difference in turnout rates between those who like news and those who prefer entertainment, both because political knowledge and turnout are tightly related and because exposure to political information motivates people to vote. People who do not like news should become less likely to go to the polls, while the reverse should happen among politically interested citizens with access to cable or the Internet. This proposition is tested by the

\footnotetext{
${ }^{7}$ The civics knowledge index is the number of correct responses to the questions about judicial review, presidential veto, maximum number of presidential terms, and the more conservative party (see appendix).
}

TABle 2 The Effect of Content Preferences on Turnout (Study 1)

\begin{tabular}{|c|c|c|}
\hline & (1) & (2) \\
\hline Cable access & $.51(.41)$ & $.38(.43)$ \\
\hline Internet access & $1.09^{* *}(.42)$ & $1.09^{* *}(.43)$ \\
\hline $\begin{array}{l}\text { Relative Entertainment } \\
\text { Preference (REP) }\end{array}$ & $.09(.11)$ & $.06(.12)$ \\
\hline REP $\times$ Cable & $-.18^{\#}(.12)$ & $-.17(.13)$ \\
\hline REP $\times$ Internet & $-.30^{* *}(.12)$ & $-.26^{*}(.12)$ \\
\hline $\begin{array}{l}\text { Turnout in } 2000 \text { House } \\
\text { Election }\end{array}$ & - & $1.05^{* *}(.16)$ \\
\hline $\begin{array}{l}\text { Wave } 1 \text { Political } \\
\text { Knowledge }\end{array}$ & $.16^{* *}(.03)$ & $.16^{* *}(.03)$ \\
\hline Sense of Civic Duty & $.22(.30)$ & $.002(.002)$ \\
\hline Education & $.23^{* *}(.06)$ & $.22^{* *}(.06)$ \\
\hline Gender & $.22^{*}(.13)$ & $.15(.14)$ \\
\hline Age & $.03^{* *}(.005)$ & $.03^{* *}(.005)$ \\
\hline Income & $.04^{*}(.02)$ & $.04^{*}(.02)$ \\
\hline $\mathrm{R}$ is married & $.41^{* *}(.14)$ & $.36^{* *}(.14)$ \\
\hline $\begin{array}{l}\text { R's primary language is } \\
\text { English }\end{array}$ & $.41(.005)$ & $.50(.48)$ \\
\hline Racial Minority & $.28(.17)$ & $.24(.18)$ \\
\hline $\begin{array}{l}\text { TV Households, Nielsen } \\
2002-3 \text { (in 1,000,000) }\end{array}$ & $-.01(.04)$ & $.00(.04)$ \\
\hline R owns home computer & $.004(.17)$ & $-.06(.17)$ \\
\hline R owns VCR & $.39^{* *}(.14)$ & $.39^{* *}(.15)$ \\
\hline $\begin{array}{l}\mathrm{R} \text { reports being registered } \\
\text { to vote }\end{array}$ & $3.38^{* *}(.33)$ & $2.77^{* *}(.34)$ \\
\hline Constant & $-8.33^{* *}(.83)$ & $-8.06^{* *}(.85)$ \\
\hline Pseudo $\mathrm{R}^{2}$ & .26 & .29 \\
\hline Log Likelihood & -762.8 & -734.4 \\
\hline $\mathrm{N}$ & 1,534 & 1,523 \\
\hline
\end{tabular}

${ }^{* *} \mathrm{p}<.01,{ }^{*} \mathrm{p}<.05,{ }^{*} \mathrm{p}<.07$ (one-tailed).

Note: Cell entries are logit coefficients and standard errors in parentheses.

models in Table 2 which regress turnout in the 2002 congressional election on Relative Entertainment Preference, access to cable and Internet, and their interactions (plus demographic controls). Consistent with the hypothesis, the logit coefficients for the interaction terms are negative and statistically significant (at $\mathrm{p}<.01$ for Internet access and $\mathrm{p}<.07$ for cable access). Including the lagged dependent variable (self-reported turnout in the 2000 House election, as measured in the first wave) in the model of 2002 turnout leaves the result largely unchanged (column 2). This is strong evidence against the alternative hypothesis that people with extreme content preferences were more likely (news-seekers) or less likely (entertainment-seekers) to turn out all along and just 


\section{FIGURE 2 Turnout and Relative Entertainment Preference}

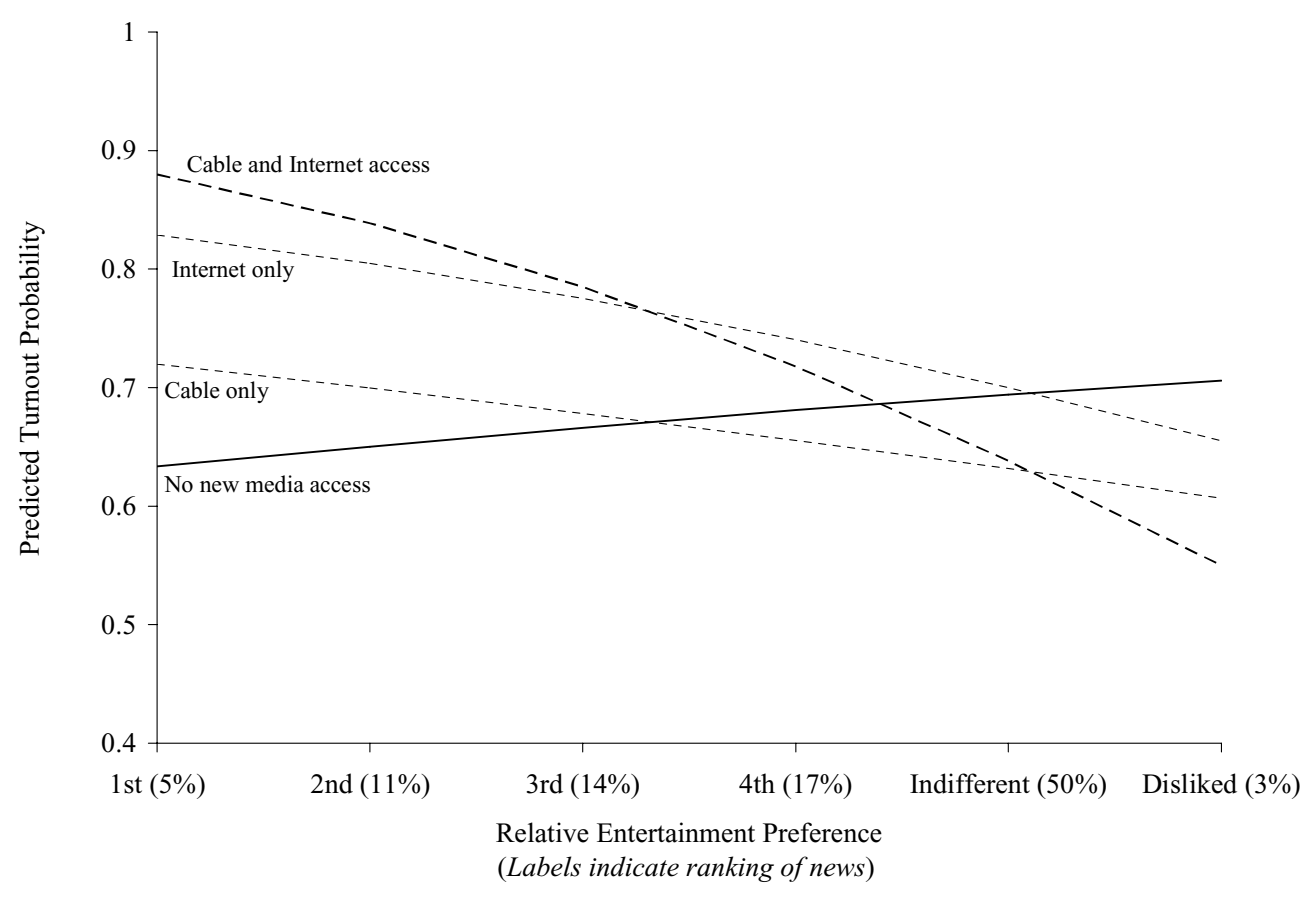

Note: This graph plots predicted values from the model in column 2 of Table 3

obtained access to cable or the Internet earlier or at higher rates than people with more moderate preferences.

Once people obtain access to new media, content preference becomes a powerful predictor of turnout, as shown by the predicted values in Figure 2 (derived from the second model in Table 2). Among respondents without either cable or Internet access, the relationship between content preference and turnout is not statistically different from zero. For cable subscribers and Internet users, in contrast, the effects of REP are sizable. Slightly more than half of the sample are indifferent towards news or dislike the genre. With access to cable and Internet, their probability of voting drops from about .69 to .64 . Roughly a third of the sample ranks news among their top three genres. For them, cable and Internet access increases the probability of voting from about .65 to .82 . Among new media users, in other words, moving from indifference to a fairly strong preference for news increases predicted turnout by almost $30 \%$. Including Wave 2 political knowledge in the models reduces the magnitude of the effects by less than a third. This result could arise for two reasons: either because my measure of political knowledge does not capture the type of knowledge most relevant to encouraging turnout or because exposure to political information motivates people to vote even when it does not affect their political knowledge. Regardless of which reason is more important, this analysis shows that greater media choice makes content preference a major influence on turnout. As in the case of political knowledge, the effect of preference exceeds the effect of education, typically one of the strongest predictors.

\section{Study 2: NES and Pew}

The N\&E Survey clearly supports the hypothesis that greater media choice increased inequality in the distributions of political knowledge and turnout. At the time of the survey, most Americans had enjoyed access to cable television for many years, and the Internet had reached about half of all households. The main purpose of replicating the analysis using additional (secondary) data-in addition to providing a general robustness check-is to determine if the results hold for different points in the diffusion process of cable TV and the Internet.

\section{Data and Measures}

Survey data for the replications come from the National Election Studies (NES) and the Media Consumption Surveys (MCS) conducted biannually by the Pew Center for the People and the Press. The NES conducts face-to-face (and, in 2000, telephone) interviews; Pew uses phone interviews. Unfortunately, the main drawback of secondary data is a big one. Neither the NES nor Pew's MCS include 
direct measures of the key concept, entertainment preference. Instead, only a few questions about exposure to entertainment shows are available. Hence, no measure derived from these data comes even close in construct validity to the measure in the N\&E Survey. The two NES data sets that ask about cable and Internet access - the NES 1996 and 2000_include a variety of knowledge items. For each data set, a knowledge measure is created by summing the number of correct responses to 14 knowledge questions (listed in the appendix). Turnout in the NES 1996 is assessed by respondent's self-reported vote in the 1996 House election. Vote measures in the Pew surveys are based on questions about voting in the last presidential (and, in the MCS 1996, House) election.

\section{Relative Entertainment Preference}

Although secondary data sources provide no direct preference measures, it is possible to approximately infer respondents' relative preferences from the type of content they report watching. High entertainment exposure per se does not necessarily indicate a greater preference for entertainment. Respondents with high entertainment exposure may watch a lot of television in general, without necessarily preferring entertainment strongly to other genres. Hence, the mix of exposure to different genres, rather than absolute exposure to entertainment alone, should be a (very rough) indicator of underlying relative preference. Respondents who watch entertainment programs but little or no news probably do so out of a preference for entertainment. High news exposure and low entertainment exposure would reflect a preference for news. The ratio of entertainment viewing to overall viewing thus yields the best possible measure of relative entertainment preference in NES and Pew data. This ratio is defined as follows:

$$
\begin{aligned}
& \text { Relative Entertainment Preference (REP) } \\
& =\frac{\text { Entertainment Viewing }}{\text { Entertainment Viewing + News Viewing }}
\end{aligned}
$$

News Viewing is the average number of days per week the respondent watched national and local news. The particular operationalization of entertainment viewing depends on the items in the surveys. For the NES 2000, entertainment viewing is average exposure to Jeopardy, Wheel of Fortune, and "television talk shows such as Oprah Winfrey, Rosie O'Donnell, or Jerry Springer." The NES 1996 measures entertainment viewing as the average daily viewing of "Jeopardy or Wheel of Fortune" and Dr Quinn, Medicine Woman. In the Pew data, entertainment viewing is operationalized as watching Entertainment Tonight,
Jerry Springer, and Oprah (MCS 2000), watching Entertainment Tonight and MTV and reading People Magazine (MCS 1998), and watching Hardcopy, Jerry Springer, and MTV (MCS 1996). All items used four-point response formats ("regularly," "sometimes," "hardly ever," "never"). REP cannot be computed for respondents who reported no information and entertainment viewing at all. These respondents are excluded from the analysis $(2.4 \%$ in the MCS 1996, 2\% in the MCS 1998, 4.5\% in the MCS 2000, $5.8 \%$ in the NES 1996, and 9.9 in the NES 2000).

The resulting REP measures range from 0 to 1 and have means of between .21 (NES 1996) and .28 (MCS 2000) with standard deviations between .19 and .28. Evidently, the ratio measures are skewed towards news preference. This is not surprising because the surveys asked about very few entertainment programs and-with the exception of the NES 2000 talk show item-only about specific programs rather than genres. Many respondents surely reported low entertainment exposure not because they do not like entertainment, but because they were not asked about their favorite shows. Yet even though the REP measures built from NES and Pew data underestimate people's preference for entertainment, they still identify a set of respondents to whom entertainment programming is relatively more attractive. To verify that measures of REP are roughly comparable for the different data sets, I examined the relationship between demographics and REP for each data source. Demographics have very similar effects on the more precise REP measure in the N\&E Survey and on the somewhat noisier ones in NES and Pew surveys.

\section{Analysis}

As before, political knowledge (Table 3) and turnout (Table 4) are regressed on access to cable TV and the Internet, Relative Entertainment Preference, and the respective interactions. Overall, the replications clearly support the hypothesis that greater media choice makes content preferences better predictors of people's political knowledge and turnout. All interactions of cable access and REP are in the predicted direction and six of the seven are statistically significant. The conditioning effect of Internet access is evident for turnout only. To summarize the joint effect of preferences and media access in these replications, I use the average of the coefficients across the two knowledge models and the five turnout models, respectively, to graph predicted values for the range of REP in Figure 3. Political knowledge of respondents without access to cable or Internet is unrelated to their content preference. For those with access to cable TV, on the other hand, moving from low to high entertainment preference corresponds to a 
TABle 3 The Effect of Content Preferences on Political Knowledge (Study 2)

\begin{tabular}{|c|c|c|}
\hline & NES 1996 & NES 2000 \\
\hline Cable Access & $.26(.22)$ & $.04(.23)$ \\
\hline Internet Access & $.15(.22)$ & $.39 *(.21)$ \\
\hline $\begin{array}{l}\text { Relative Entertainment } \\
\text { Preference (REP) }\end{array}$ & $-.17(.60)$ & $.06(.59)$ \\
\hline REP $\times$ Cable & $-1.33^{*}(.68)$ & $-1.38^{*}(.64)$ \\
\hline REP $\times$ Internet & $.80(.68)$ & $.09(.52)$ \\
\hline Education & $.44^{* *}(.05)$ & $.58^{* *}(.05)$ \\
\hline Gender & $-.64^{* *}(.15)$ & $-.88^{* *}(.14)$ \\
\hline Age & $.03^{* *}(.01)$ & $.04^{* *}(.005)$ \\
\hline Income (MV imputed) & $.07^{* *}(.02)$ & $.08^{* *}(.02)$ \\
\hline Income was imputed & $-.22(.26)$ & $-.14(.19)$ \\
\hline African American & $-1.35^{* *}(.25)$ & $-.78^{* *}(.24)$ \\
\hline Hispanic or Latino & - & $-.41(.31)$ \\
\hline Other Minority & $-.15(.45)$ & $-.07(.30)$ \\
\hline $\begin{array}{l}\text { R works } 20+\text { hours per } \\
\text { week }\end{array}$ & $.10(.18)$ & $-.38^{*}(.17)$ \\
\hline $\mathrm{R}$ lives in the South & $-.31^{*}(.16)$ & $-.74^{* *}(.15)$ \\
\hline Party ID & $.02(.03)$ & $-.02(.04)$ \\
\hline Strength of Party ID & $.37^{* *}(.08)$ & $.43^{* *}(.07)$ \\
\hline $\begin{array}{l}\text { Frequency of political } \\
\text { discussion with } \\
\text { friends or family }\end{array}$ & $1.60^{* *}(.24)$ & $1.29^{* *}(.17)$ \\
\hline Constant & $3.52^{* *}(.46)$ & $-.25(.44)$ \\
\hline $\mathrm{R}^{2}$ & .29 & .40 \\
\hline $\mathrm{N}$ & 1,284 & 1,334 \\
\hline
\end{tabular}

${ }^{* *} \mathrm{p}<.01,{ }^{*} \mathrm{p}<.05$ (one-tailed).

Note: Cell entries are unstandardized OLS coefficients and standard errors in parentheses.

$20 \%$ drop in political knowledge. The effect of REP among Internet users is insignificant and not even in the predicted direction. This result is the only instance in this article in which a hypothesis is not supported. The turnout effects mirror the N\&E analysis quite precisely. The likelihood of turnout among people without access to cable or Internet is just above chance regardless of their entertainment preference. For those with cable and the Internet, the likelihood of casting a vote drops from a three-quarter chance among people with the least interest in entertainment to less than .4 among those with the strongest preference for entertainment.

Beyond replicating the $\mathrm{N} \& \mathrm{E}$ results, the analysis of NES and Pew data adds an important element by demonstrating that access to cable and Internet conditioned the effect of preferences as early as 1996 (the first year for which we have data to test the hypothesis). According to a competing hypothesis, respondents with strong content preferences may have had access to these media earlier. In that case, the finding that political knowledge and turnout are higher among news-seekers and lower among entertainment-seekers with greater media choice would not imply any changes in knowledge and turnout levels, only that these two segments were the most and least knowledgeable in the first place. The fact that Relative Entertainment Preference consistently had a sizable effect among cable viewers and Internet users between 1996 and 2003 makes this claim hard to sustain. During this period, the percentage of cable subscribers rose from 69\% in 1996 (MCS 1996) to 81\% in 2003 (N\&E Survey), and the percentage of Americans with Internet access increased from a mere 21\% in April of 1996 (MCS 1996) to 62\% in 2000 (NES 2000). At some point in this diffusion process, even people with moderate content preferences would have obtained access to new media. Yet this analysis has shown significant effects both in 1996, when only 15\% of population had access to both cable and the Internet, and in 2000 , when $53 \%$ did. It thus becomes impossible to argue that over the period of this analysis, respondents with strong content preferences were always more likely to have greater media choice. The effect of increased choice appears to be quite stable over the past decade, even though more and more people gained access to cable TV and the Internet.

Successful replication minimizes concerns about one other methodological issue: Knowledge Networks, the company which conducted the N\&E Survey, provides its respondents with WebTV to conduct periodic interviews. Strictly speaking, the N\&E Survey therefore does not permit inferences about the effect of Internet access. Although WebTV is much less convenient than using a regular browser and a mouse, even N\&E respondents with only WebTV access are not a genuine 'no Internet' group. This is not a major concern here because if anything it would produce conservative estimates of the true effect. If respondents with WebTV as their only means of using the Internet did indeed behave just as Internet users with dial-up or broadband connections, then Internet access as I define it in the N\&E Survey should not condition the effect of content preference at all. That Internet access does significantly boost the impact of content preference suggests that accessing the Internet on a television set is not quite the same thing as even a dial-up connection. Still, replicating results on data sets that include respondents with no Internet connection at all bolsters the robustness of my findings. Substantively, the more important point is that differences in the efficiency of media access probably matter as much as the difference between no access and presently typical dial-up connections. As Internet 
TABle 4 The Effect of Content Preferences on Turnout (Study 2)

\begin{tabular}{|c|c|c|c|c|c|}
\hline & \multirow{2}{*}{$\begin{array}{l}\text { NES } 1996 \\
1996 \text { House }\end{array}$} & \multirow{2}{*}{$\begin{array}{l}\text { Pew } 2000 \\
1996 \text { Pres. }\end{array}$} & \multirow{2}{*}{$\begin{array}{l}\text { Pew } 1998 \\
1996 \text { Pres. }\end{array}$} & \multicolumn{2}{|c|}{ Pew 1996} \\
\hline & & & & 1992 Pres. & 1994 House \\
\hline Cable & $.49^{* *}(.21)$ & $.25^{* *}(.11)$ & $.18^{*}(.10)$ & $.59^{* *}(.15)$ & $.36^{*}(.14)$ \\
\hline Internet & $.21(.21)$ & $.62^{* *}(.11)$ & $.54^{* *}(.12)$ & $.58^{* *}(.18)$ & $.34^{*}(.17)$ \\
\hline REP & $.44(.54)$ & $.08(.27)$ & $.05(.24)$ & $-.84^{*}(.38)$ & $-.64(.40)$ \\
\hline REP $\times$ Cable & $-1.28^{*}(.61)$ & $-.57^{*}(.29)$ & $-.26(.28)$ & $-.99^{*}(.44)$ & $-1.15^{*}(.46)$ \\
\hline REP $\times$ Internet & $.39(.66)$ & $-.67^{* *}(.28)$ & $-.79^{* *}(.30)$ & $-1.11^{*}(.52)$ & $-.10(.53)$ \\
\hline Education & $.31^{* *}(.05)$ & $.22^{* *}(.02)$ & $.26^{* *}(.02)$ & $.23^{* *}(.03)$ & $.22^{* *}(.03)$ \\
\hline $\begin{array}{l}\text { Income } \\
\text { (Imputations for MV) }\end{array}$ & $.07^{* *}(.01)$ & $.10^{* *}(.02)$ & $.11^{* *}(.02)$ & $.08^{* *}(.02)$ & $.15^{* *}(.02)$ \\
\hline Income Missing & $.21(.27)$ & $-.91^{* *}(.09)$ & $-.79^{* *}(.08)$ & $-.60^{* *}(.14)$ & $.07(.14)$ \\
\hline Gender & $.19(.14)$ & $-.10(.06)$ & $.13^{*}(.06)$ & $-.21^{* *}(.08)$ & $-.13^{*}(.08)$ \\
\hline Age & $.04^{* *}(.005)$ & $.04^{* *}(.002)$ & $.04^{* *}(.002)$ & $.04^{* *}(.003)$ & $.05^{* *}(.003)$ \\
\hline Employment Status & $.09(.17)$ & $.19^{* *}(.07)$ & $.17^{* *}(.07)$ & $.26^{* *}(.08)$ & $-.19 *(.08)$ \\
\hline Size of Town & - & $-.07 *(.03)$ & $-.02(.03)$ & $-.02(.04)$ & $.05(.04)$ \\
\hline Party ID & $.11^{* *}(.04)$ & - & - & - & - \\
\hline Strength of Party ID & $.61^{* *}(.08)$ & - & - & - & - \\
\hline Constant & $-4.87^{* *}(.46)$ & $-3.25^{* *}(.21)$ & $-3.19^{* *}(.18)$ & $-2.45^{* *}(.26)$ & $-3.70^{* *}(.27)$ \\
\hline -2 Log-likelihood & $1,354.9$ & $6,219.8$ & $7,121.8$ & $4,180.4$ & $4,179.3$ \\
\hline $\mathrm{N}$ & 1,410 & 2,910 & 2,856 & 1,674 & 1,620 \\
\hline
\end{tabular}

${ }^{* *} \mathrm{p}<.01,{ }^{*} \mathrm{p}<.05$ (one-tailed).

Note: Cell entries are logit coefficients and standard errors in parentheses.

connections become faster, the impact of content preferences is likely to increase further.

In sum, replication using a number of different data sets was successful. The hypothesized conditioning effect of media choice has been shown for very different points in the diffusion process of cable TV and the Internet (1996-2003), for different interview modes (phone, face-to-face, and web-based) and political contexts (during election campaigns and mid-term), as well as for different measures of Relative Entertainment Preference.

\section{Conclusion}

When speculating about the political implications of new media, pundits and scholars tend to either praise the likely benefits for democracy in the digital age or dwell on the dangers. The optimists claim that the greater availability of political information will lead more people to learn more about politics and increase their involvement in the political process. The pessimists fear that new media will make people apolitical and provide mind-numbing entertainment that keeps citizens from fulfilling their democratic responsibilities. These two predictions are often presented as mutually exclusive. Things will either spiral upwards or spiral downwards; the circle is either virtuous or vicious. The analyses presented here show that both are true. New media do indeed increase political knowledge and involvement in the electoral process among some people, just as the optimists predict. Yet, the evidence supports the pessimists' scenario as well. Other people take advantage of greater choice and tune out of politics completely. Those with a preference for entertainment, once they gain access to new media, become less knowledgeable about politics and less likely to vote. People's media content preferences become the key to understanding the political implications of new media.

Analog cable systems and dial-up Internet connections-currently the most common ways of new media access - are only the first technological steps towards greater choice. Digital technology will multiply the number of choices and the efficiency of choosing, thereby further increasing the impact of content preferences on users' choices. This study has begun to show this impact, but it has also raised new questions: How are content preferences formed? How easily do they change? What changes them? A measure of content preferences not used in this study was included in both panel waves of the N\&E Survey. Overtime correlations of .6 (Pearson's r) suggest considerable preference stability. In light of the 


\section{Figure 3 Pew and NES Replications, Average Effects on Political Knowledge and Turnout}

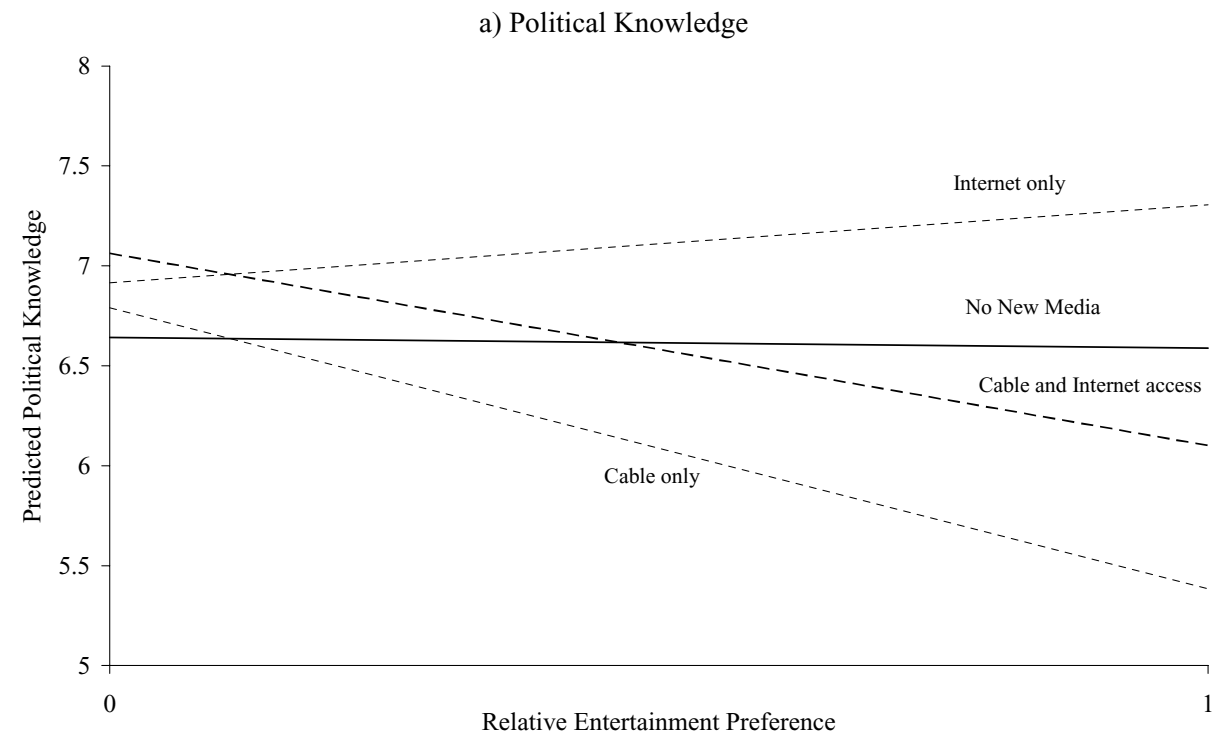

b) Turnout

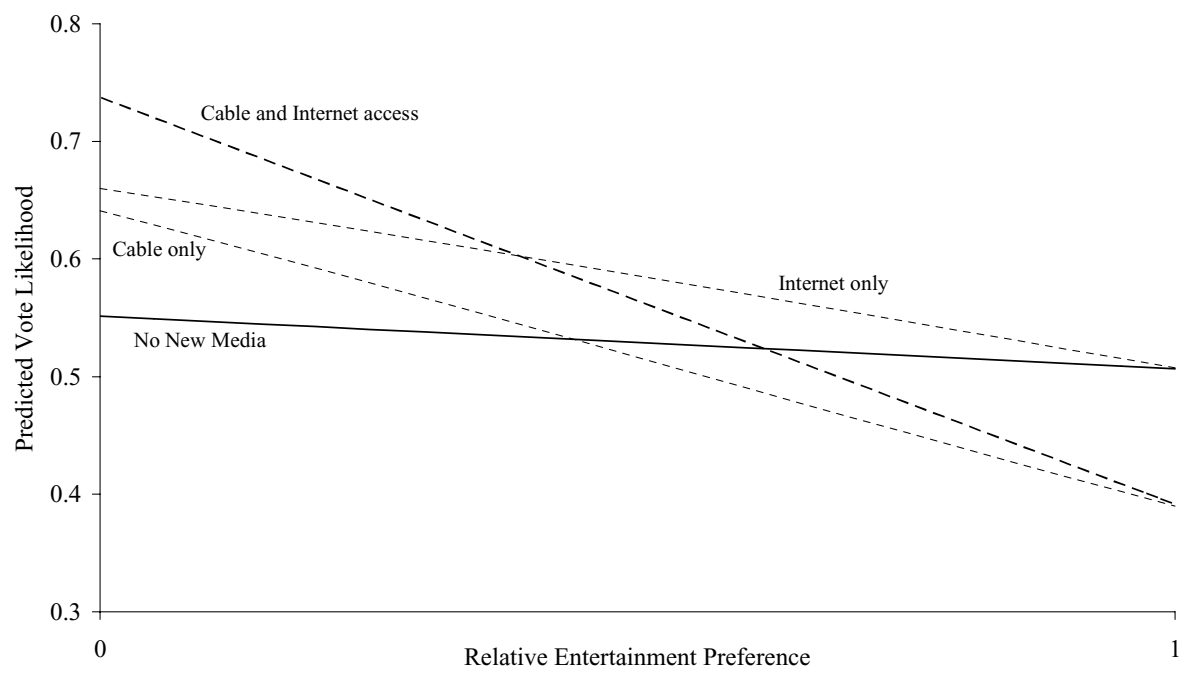

Note: This graph plots predicted values based on the average of the coefficients in Table 4

powerful effects content preferences had in this study, the next logical step is to examine if and how political socialization, education, or the content and style of political news affect people's preferences.

The decline in the size of news audiences over the last three decades has been identified as cause for concern by many observers who have generally interpreted it as a sign of waning political interest and a disappearing sense of civic duty. Yet changes in available content can affect news consumption and learning even in the absence of preference changes. People's media use may change in a modified media environment, even if their preferences (or political interest or sense of civic duty) remain constant. By this logic, the decreasing size of the news audience is not necessarily an indication of reduced political interest. Interest in politics may simply never have been as high as audience shares for evening news suggested. A combined market share for the three network newscasts of almost $90 \%$ takes on a different meaning if one considers that people had hardly any viewing alternatives. It was "politics by default" (Neuman 1996, 19), not politics by choice. Even the mediocre levels of political knowledge during the broadcast era (e.g., Delli Carpini and Keeter 1996), in other words, were partly a result of de facto 
restrictions of people's freedom to choose their preferred media content.

Ironically, we might have to pin our hopes of creating a reasonably evenly informed electorate on that reviled form of communication, political advertising. Large segments of the electorate in a high-choice environment do not voluntarily watch, read, or listen to political information. Their greatest chance for encounters with the political world occurs when commercials are inserted into their regular entertainment diet. And exposure to political ads can increase viewers' political knowledge (Ansolabehere and Iyengar 1995). At least for the time being, before recording services like TiVo, which automatically skip the commercial breaks, or subscriber-financed premium cable channels without advertising become more widespread, political advertising is more likely than news coverage to reach these viewers.

It might seem counterintuitive that political knowledge has decreased for a substantial portion of the electorate even though the amount of political information has multiplied and is more readily available than ever before. The share of politically uninformed people has risen since we entered the so-called "information age." Television as a medium has often been denigrated as "dumb," but, helped by the features of the broadcast environment, it may have been more successful in reaching less interested segments of the population than the "encyclopedic" Internet. In contrast to the view that politics is simply too difficult and complex to understand, this study shows that motivation, not ability, is the main obstacle that stands between an abundance of political information and a welland evenly informed public.

When differences in political knowledge and turnout arise from inequality in the distribution of resources and skills, recommendations for how to help the information have-nots are generally uncontroversial. To the extent that knowledge and turnout gaps in the new media environment arise from voluntary consumption decisions, recommendations for how to narrow them, or whether to narrow them at all, become more contestable on normative grounds. As Downs remarked a long time ago, "[t]he loss of freedom involved in forcing people to acquire information would probably far outweigh the benefits to be gained from a better-informed electorate" $(1957,247)$. Even if a consensus emerged to reduce media choice for the public good, it would still be technically impossible, even temporarily, to put the genie back in the bottle. Avoiding politics will never again be as difficult as it was in the "golden age" of television.

\section{Appendix Description of Knowledge Measures}

\section{N\&E Survey}

Political Knowledge, Wave 1, 12-item index

"Which of the following countries shares a border with Afghanistan?” (Russia/Pakistan/Iraq Kazakhstan)

"In the war in Afghanistan, which of the following groups fought on the side of the coalition led by the United States and Britain?" (The Islamic Jihad/The Taliban/The Northern Alliance/Al-Qaeda)

"Which of the following agencies was founded in the wake of the terrorist attacks on September 11?" (Office for Homeland Security/Delta Force/National Security Agency/Department of Civilian Defense)

"Would you say there is more, less, or about the same amount of crime in the United States today as compared to 10 years ago?" (more/less/same)

"Please give me your best guess for this next question. For every dollar spent by the federal government in Washington, how much of each dollar do you think goes for foreign aid to help other countries?" (following Gilens (2001), $5 \%$ or less is coded as correct)

"Do you happen to know which party currently has the most members in the House of Representatives in Washington?" (Democrats/Republicans)

"Whose responsibility is it to determine if a law is constitutional or not?" (President/Congress/Supreme Court)

"How much of a majority is required for the US Senate and House to override a presidential veto?" (one-half plus one vote/three-fifths/two-thirds/three quarters)

"How many four-year terms can the president of the United States serve?" (1/2/3/unlimited number of terms)

"In general, thinking about the political parties in Washington, would you say that Democrats are more conservative than Republicans, or Republicans are more conservative than Democrats?" (Democrats more conservative/Republicans more conservative)

"On this page, you see four photographs. Do you happen to know which of the photographs shows John McCain?"

"On this page, you see four photographs. Do you happen to know which of the photographs shows Vladimir Putin?"

Cronbach's alpha $=.70$, mean $=8.0$, s.d. $=2.4$ 
Political Knowledge, Wave 2, 15-item index

"Who is the current secretary of defense?" (Donald Rumsfeld/John Ashcroft/George Tenet/Colin Powell)

"Who is the current Senate majority leader?" (Bill Frist/Trent Lott/Dick Gephardt/John Kerry)

"Who is the Chief Justice on the U.S. Supreme Court?" (William Rehnquist/Clarence Thomas/Antonin Scalia/Anthony Kennedy)

"What office is currently held by Condoleezza ("Condi") Rice?" (U.S. Attorney General/National Security Adviser/Secretary of Defense/White House Chief of Staff)

"What position is currently held by Ari Fleischer?" (White House Chief of Staff/White House Press Secretary/Education Secretary/Senior Presidential Campaign Advisor)

"What position is currently held by Alan Greenspan?" (Director of the Central Intelligence Agency/Treasury Secretary/Chairman of the Federal Reserve/Commerce Secretary)

"For each of the following politicians, please indicate to which party they belong: Tom Daschle, Christine Todd Whitman, Howard Dean, Ralph Nader." (Republican, Democrat, Green Party, Reform Party)

"Do you happen to know which party currently has the most members in the House of Representatives in Washington?” (Democrats/Republicans)

"Do you happen to know which party currently has the most members in the Senate?" (Democrats/Republicans)

"Whose responsibility is it to determine if a law is constitutional or not?" (President/Congress/Supreme Court)

"How much of a majority is required for the US Senate and House to override a presidential veto?" (one-half plus one vote/three-fifths/two-thirds/three quarters)

"In general, thinking about the political parties in Washington, would you say that Democrats are more conservative than Republicans, or Republicans are more conservative than Democrats?" (Democrats more conservative/Republicans more conservative)

Note: One half of the respondents were randomly assigned to a visual condition in which photographs of the politicians instead of their names were shown on screen. For the purpose of this study, I simply average across this (random) variation.

Cronbach's alpha $=.83$, mean $=8.3$, s.d. $=3.8$

\section{NES 2000}

\section{Political Knowledge, 14-item index}

Knows which party had majority in the House before election

Knows which party had majority in the Senate before election

Correctly responds that Trent Lott's current job is Senate majority leader (open-ended)

Correctly responds that William Rehnquist's current job is chief justice of the Supreme Court (open-ended)

Correctly responds that Tony Blair's current job is prime minister of England/Great Britain (open-ended)

Correctly responds that Janet Reno's current job is attorney general (open-ended)

Correct recall of incumbent/challenger

Correct recognition of incumbent/challenger (rated on feeling thermometer)

Correctly identifies incumbent in the district

Remembers something about incumbent in district

Gives response other than 'Don't Know' to "Do you happen to know about how many years [incumbent] has been in the House of Representatives?"

Gives response other than 'Don't Know' to “How good a job would you say U.S. Representative [NAME] does of keeping in touch with the people in your district?"

mean $=4.97$, s.d. $=3.18$

\section{NES 1996}

\section{Political Knowledge, 14-item index}

Knows which party had majority in the House before election

Knows which party had majority in the Senate before election

Correctly responds that Al Gore's current job is vicepresident (open-ended)

Correctly responds that William Rehnquist's current job is chief justice of the Supreme Court (open-ended)

Correctly responds that Boris Yelsin's current job is president (leader) of Russia (open-ended)

Correctly responds that Newt Gingrich's current job is Speaker of the House (open-ended)

Correct recall of incumbent/challenger 
Correct recognition of incumbent/challenger (rated on feeling thermometer)

Correctly identifies incumbent in the district

Gives response other than 'Don't Know' to “Did Representative [NAME] vote for or against the welfare reform bill?"

Gives response other than 'Don't Know' to "How often has Representative [NAME] supported President Clinton's legislative proposals?"

Gives response other than 'Don't Know' to "How good a job would you say U.S. Representative [NAME] does of keeping in touch with the people in your district?"

mean $=8.43$, s.d. $=3.07$

\section{References}

Ansolabehere, Stephen, and Shanto Iyengar. 1995. Going Negative: How Attack Ads Shrink and Polarize the Electorate. New York: Free Press.

Bartels, Larry M., and Wendy M. Rahn. 2000. "Political Attitudes in the Post-Network Era." Presented at the Annual Meeting of the American Political Science Association, Washington.

Barwise, T. P., A. S. C. Ehrenberg, and G. J. Goodhardt. 1982. "Glued to the Box. Patterns of Tv Repeat-Viewing." Journal of Communication 32(4):22-29.

Baum, Matthew A. 2002. "Sex, Lies, and War: How Soft News Brings Foreign Policy to the Inattentive Public." American Political Science Review 96(1):91-110.

Baum, Matthew A., and Samuel Kernell. 1999. "Has Cable Ended the Golden Age of Presidential Television?" American Political Science Review 93(1):99-114.

Becker, Lee B., and Klaus Schönbach. 1989. "When Media Content Diversifies: Anticipating Audience Behaviors.” In Audience Responses to Media Diversification: Coping with Plenty, ed. Lee B. Becker and Klaus Schönbach. Hillsdale: Lawrence Erlbaum Associates Inc., pp. 1-27.

Bowman, Gary. 1975. "Consumer Choice and Television.” Applied Economics 7(3):175-84.

Delli Carpini, Michael X., and Scott Keeter. 1996. What Americans Know About Politics and Why It Matters. New Haven: Yale University Press.

Downs, Anthony. 1957. An Economic Theory of Democracy. New York: Harper.

Epstein, Jay Edward. 1973. News from Nowhere. New York: Random House.

Eveland, William P., Jr., and Dietram A. Scheufele. 2000. "Connecting News Media Use with Gaps in Knowledge and Participation." Political Communication 17(3):215-37.

Gaziano, Cecilie. 1997. "Forecast 2000: Widening Knowledge Gaps." Journalism and Mass Communication Quarterly 74(2):237-64.

Gilens, Martin. 2001. "Political Ignorance and Collective Policy Preferences.” American Political Science Review 95(2):37996.
Gilens, Martin, Lynn Vavreck, and Martin Cohen. 2004." See Spot Run: The Rise of Advertising, the Decline of News, and the American Public's Perceptions of Presidential Candidates, 1952-2000. “Presented at the Annual Meeting of the Midwest Political Science Association.

Graber, Doris A. 1988. Processing the News: How People Tame the Information Tide. 2nd ed. New York: Longman.

Heeter, Carrie. 1985. "Program Selection with Abundance of Choice: A Process Model." Human Communication Research 12(1):126-52.

Keeter, Scott, and Harry Wilson. 1986. "Natural Treatment and Control Settings for Research on the Effects of Television." Communication Research 13(1):37-53.

Klein, Paul. 1972. "The Television Audience and Program Mediocrity." In Mass Media and Society, ed. Alan Wells. Palo Alto: National Press Books, pp. 76-79.

Krosnick, Jon A., and Lin Chiat Chang. 2001. "A Comparison of the Random Digit Dialing Telephone Survey Methodology with Internet Survey Methodology as Implemented by Knowledge Networks and Harris Interactive." Unpublished manuscript. The Ohio State University.

Krotki, Karol, and J. Michael Dennis. 2001. "Probability-Based Survey Research on the Internet." Paper presented at the 53rd Conference of the International Statistical Institute, Seoul, South Korea.

Krugman, Herbert E., and Eugene L. Hartley. 1970. "Passive Learning from Television." Public Opinion Quarterly 34(2):184-90.

Kwak, Nojin. 1999. "Revisiting the Knowledge Gap Hypothesis: Education, Motivation, and Media Use." Communication Research 26(4):385-413.

Lehmann, Donald R. 1971. "Television Show Preference: Application of a Choice Model." Journal of Marketing Research 8(1):47-55.

LoSciuto, Leonard A. 1972. "A National Inventory of Television Viewing Behavior.” In Television and Social Behavior. Television in Day-to-Day Life: Patterns of Use, ed. Eli A. Rubinstein, George A. Comstock and John P. Murray. Washington: U.S. Government Printing Office, pp. 33-86.

National Telecommunications and Information Administration. 2002. A Nation Online: How Americans Are Expanding Their Use of the Internet. Washington: U.S. Department of Commerce.

Negroponte, Nicholas. 1995. Being Digital. New York: Knopf.

Neuman, W. Russell. 1976. "Patterns of Recall among Television News Viewers.” Public Opinion Quarterly 40(1):115-23.

Neuman, W. Russell. 1996. "Political Communication Infrastructure." The Annals of the American Academy of Political and Social Science 546(July):9-21.

Neuman, W. Russell, Marion R. Just, and Ann N. Crigler. 1992. Common Knowledge: News and the Construction of Political Meaning. Chicago: University of Chicago Press.

Palfrey, Thomas R., and Keith T. Poole. 1987. "The Relationship between Information, Ideology, and Voting Behavior." American Journal of Political Science 31(3):511-30.

Rubin, Alan M. 1984. "Ritualized and Instrumental Television Viewing." Journal of Communication 34(3):67-77.

Sunstein, Cass R. 2001. Republic.Com. Princeton: Princeton University Press. 
Tichenor, Philip J., George A. Donohue, and Calice A. Olien. 1970. "Mass Flow and Differential Growth in Knowledge." Public Opinion Quarterly 34(2):149-70.

Verba, Sidney, Kay Lehman Schlozman, and Henry E. Brady. 1995. Voice and Equality: Civic Voluntarism in American Politics. Cambridge: Harvard University Press.

Viswanath, Kasisomayajula, and John R. Finnegan, Jr. 1996. "The Knowledge Gap Hypothesis: Twenty-Five Years Later." In Communication Yearbook, ed. Brant Burleson. Thousand Oaks: Sage Publications, pp. 187-227.

Webster, James G. 1984. “Cable Television's Impact on Audience for Local News.” Journalism Quarterly 61(2):419-22.
Webster, James G., and Gregory D. Newton. 1988. "Structural Determinants of the Television News Audience." Journal of Broadcasting \& Electronic Media 32(4):381-89.

Youn, Sug-Min. 1994. "Program Type Preference and Program Choice in a Multichannel Situation." Journal of Broadcasting \& Electronic Media 38(4):465-75.

Zhao, Xinshu, and Steven H. Chaffee. 1995. "Campaign Advertisements Versus Television News as Sources of Political Issue Information.” Public Opinion Quarterly 59(1):41-65.

Zukin, Cliff, and Robin Snyder. 1984. "Passive Learning: When the Media Environment Is the Message." Public Opinion Quarterly 48(3):629-38. 